\title{
EFFECT OF CONTINUOUS AND INTERMITTENT AERATION ON COMPOSTING OF POULTRY LITTER AND COTTON STALKS
}

\author{
Mohamed A. Basiouny ${ }^{1}$
}

\begin{abstract}
The present study was carried out at Rice Mechanization Center, Meet El-Deeba, Kafrelsheikh governorate, Egypt during the year of 2013. The influence of forced aeration modes (continuous and intermittent aeration) at three levels of aeration rates of $0.13,0.16$ and $0.19 \mathrm{~m}^{3} / \mathrm{h}$ on composting of poultry litter and cotton stalks were studied using metal vessels. Three various levels of intermittent aeration (45, 30 and $15 \mathrm{~min} / \mathrm{h})$ were tested. Temperature was monitored and recorded as the most important indicator of the efficiency and effectiveness of the composting process. Also, the moisture content and Carbon:Nitrogen $(C: N)$ ratio of the initial composting mixture were adjusted at about $61.53 \%$ and $32: 1$, respectively. The moisture content and $\mathrm{pH}$ value were measured during composting process. Total organic matter, bulk density, electrical conductivity, total nitrogen and total organic carbon were measured on the initial composting mixture and at the final composting product. Moreover, the most important results showed that the maximum temperature of $65.45^{\circ} \mathrm{C}$ (at thermophilic phase) was recorded after twenty-six days from the beginning of composting time at the intermittent aeration of $30 \mathrm{~min} / \mathrm{h}$ and the aeration rate of $0.16 \mathrm{~m}^{3} / \mathrm{h}$. In all vessels the moisture content and $C: N$ ratio decreased and were proportional to temperature and aeration conditions. However, the lowest time for cooling down and maturing compost was of sixty-four days at 30min/h and $0.16 \mathrm{~m}^{3} / \mathrm{h}$ aeration conditions. The initial bulk density of the mixture compost materials decreased from 34.8 to $13.9 \%$ at the end composting process depending on the aeration conditions.
\end{abstract}

${ }^{1}$ Senior researcher in Agric. Eng. Res. Inst. (AEnRI), ARC, Giza, Egypt. 


\section{INTRODUCTION}

The environmental problems associated with raw poultry manure application could be mitigated by stabilizing its nutrient and

1 organic matter contents by composting before application to agricultural soils (Tiquia and Tam, 2002). The crop residues are byproducts of common crops such as cotton, rice and maize. The total amount of residues reaches about 38.28 million tons per year. Cotton residues represent about $9 \%$ of the total amount of residues. These materials are comprising mainly cotton stalks, which present a disposal problem (G.M.A.S 2006, in Arabic). Composting is a method of solid waste management where the organic component of the organic waste is biologically decomposed and stabilized under controlled conditions to a state where it can be handled, stored and applied to the land to supply essential nutrients without adversely affecting on the environment. The aerobic condition during composting process is a critical factor determining the discharge of unwanted emissions (Smet et al., 1999). High oxygen levels can be maintained by choosing different aeration systems and designing various aeration rates and on/off cycles ( $\mathrm{Li}$ et al., 2008 and Kim et al., 2009). Different methods to maintain an aerobic fermentation condition in composting reactor include pile turning, forced aeration of static pile, and passive aeration of static pile (Solano et al., 2001). To enhance the rapid growth of aerobic and facultative microorganisms for decomposing organic materials (Polprasert, 1996). The traditional method to aerate a pile of compost depends on mechanical equipment to turn over the material twice daily to once every other day. After stirring, the compost has the highest oxygen content but the oxygen gradually depletes so that anaerobic conditions may develop in the compost until the next stirring. While the stirring provides oxygen, and also disperses the odor to cause serious environmental pollution. The odorous emission is difficult to control with mechanical aeration. It causes the general public to complain about the odor and even appeal to regulatory agencies for the problem. Additionally, traditional mechanical composting may be take as long as 2-6 months to mature (Solano et al., 2001 and Trois and Polster, 2001). How to shorten the composting time and alleviate the odor problem is an emerging topic for research on 
composting technology. Using the forced-air (positive pressure) aeration that blows air from the bottom of the composting container to diffuse air upward for aeration will maintain a favorable composting environment to reduce the composting time to about 28-35 days ( $\mathrm{Li}$ et al., 2008). In order to achieve a successful composting, the influencing factors such as temperature, moisture content, aeration rate, $\mathrm{pH}, \mathrm{C} / \mathrm{N}$ ratio, and composting materials should be appropriately controlled. In biological terms, the operating temperature ranges are as follows: $>55^{\circ} \mathrm{C}$ to maximize sanitation, $45-55^{\circ} \mathrm{C}$ to maximize the biodegradation rate, and $35-40^{\circ} \mathrm{C}$ to maximize the microbial diversity (Hassen et al., 2001). The process of aerobic composting can be divided into three phases: a mesophilic-heating phase (warming up, to $40^{\circ} \mathrm{C}$ ), a thermophilic-heating phase (peak temperature, $40-70^{\circ} \mathrm{C}$ ) and a cooling phase (Pereia-Neto et al., 1987). Kulcu and Yaldiz (2004) stated that the higher dry and organic matter lost were observed in the reactor had the higher aeration rate and the decrease more pronounced during the first stages process. Among the influencing factors of composting, aeration rate is regarded as one of the key factors affecting composting process and compost quality. The efficiency of an aerobic composting system is closely related to the aeration rate. The aeration rate affects microbial activity, substrate degradation rate, and temperature variation in the composting process (Kuter et al., 1985). Too little aeration may lead to anaerobic conditions, however, too much aeration may also lead to excessive cooling, preventing the thermophilic conditions required for optimum rates of decomposition (Ahn et al., 2007). Therefore, it is important that the amount of aeration is managed at the appropriate level to conduct the composting process efficiently. Different aeration rate were recommended in some previous studies, such as $0.87-1.071 \mathrm{~min}^{-1} \mathrm{~kg}^{-1}$ OM (Organic Matter) in composting of dairy cattle manure with crop and forest residues (Hong et al., 1983), $0.251 \mathrm{~min}^{-1} \mathrm{~kg}^{-1} \mathrm{OM}$ in the composting dairy manure with rice straw ( $\mathrm{Li}$ et al., 2008), 0.43-0.86 1 $\mathrm{min}^{-1} \mathrm{~kg}^{-1} \mathrm{OM}$ in the composting of food waste (Lu et al., 2001), 0.04$0.081 \mathrm{~min}^{-1} \mathrm{~kg}^{-1} \mathrm{OM}$ for swine manure composting (Lau et al., 1992), and initial $0.4-0.91 \mathrm{~min}^{-1} \mathrm{~kg}^{-1} \mathrm{OM}$ followed $0.41 \mathrm{~min}^{-1} \mathrm{~kg}^{-1} \mathrm{OM}$ at the later phase of composting in an active municipal solid waste system 
(Rasapoor et al., 2009). These results showed the optimal aeration rate might be closely related to the composition of composting materials in the different composting processes. Therefore, the optimal range of aeration rate is variable due to the dissimilarity of composting material in the different composting process. Therefore, the objective of the present study was to investigate the effectiveness of forced aeration modes (continuous and intermittent aeration) at different aeration rates during the composting process.

\section{MATERIALS AND METHODS}

The experiments were carried out at Rice Mechanization Center, Meet El-Deeba, Kafrelsheikh governorate, Egypt during the year of 2013.

\section{Composting materials:}

The poultry litter (a mixture of broiler droppings, chopped rice straw, waste feed, and feathers) that used in the present study was obtained from the poultry houses in Kafrelsheikh governorate, Egypt. Cotton stalk (Giza 180 variety) was used as bulking agent to increase compost porosity. However, cotton stalk was chopped by using a chopping machine in order to obtain small pieces with dimensions ranging from 1 to $2 \mathrm{~cm}$. A mixture of cotton stalks and poultry litter at a ratio of 3:1. Poultry litter and cotton stalks were mixed to adjust the initial moisture contents of about $61.53 \%$ (w.b.) in all experiments. Then, the mixture was placed in each vessel which occupied $90 \%$ of the total volume of the vessel. Some physicochemical properties of the composted raw material and its mixture are listed in Table 1.

Table 1: Some physicochemical properties of the composted raw materials and its mixture.

\begin{tabular}{|c|c|c|c|}
\hline \multirow{2}{*}{ Parameter } & \multicolumn{2}{|c|}{ Raw materials } & \multirow{2}{*}{$\begin{array}{l}\text { Initial composting } \\
\text { mixture }\end{array}$} \\
\hline & Cotton stalk & Poultry litter & \\
\hline Moisture content, \%w.b. & 22.41 & 63.85 & 61.53 \\
\hline $\mathrm{pH}$ & 6.69 & 7.83 & 7.15 \\
\hline Total organic carbon, $\mathrm{g} / \mathrm{kg}$ & 456.4 & 282.3 & 348.75 \\
\hline Total nitrogen, $\mathrm{g} / \mathrm{kg}$ & 7.3 & 21.4 & 10.89 \\
\hline $\mathrm{C} / \mathrm{N}$ ratio & 62.5 & 13.2 & $32: 1$ \\
\hline $\begin{array}{l}\text { Electrical conductivity, } \\
\mathrm{dS} / \mathrm{m}\end{array}$ & 3.74 & 4.23 & 3.87 \\
\hline Bulk density, $\mathrm{kg} / \mathrm{m}^{3}$ & 187.56 & 597.34 & 362.47 \\
\hline
\end{tabular}




\section{Composting vessel:}

Tests were conducted using 12 identical cylindrical vessels, $132 \mathrm{~cm}$ high and $65 \mathrm{~cm}$ in diameter. Vessels were fabricated from galvanized steel sheet with $3 \mathrm{~mm}$ thick and it had free volume of $0.372 \mathrm{~m}^{3}$. For aeration purposes, an air plenum, $20 \mathrm{~cm}$ in height, was created at the bottom of each vessel using a supporting metal wire mesh. The aeration was provided by four similar blowers and each blower has an electric motor of $1.0 \mathrm{~kW}$. The blower was used to furnish air to the three vessels at different aeration rates. Air supplied by the blower passed through PVC pipes of inner diameter of $7.5 \mathrm{~cm}$. The aeration rate supplied to each vessel was controlled by ball valve located on the entrance of the plenum chamber of the vessel. The intermittent aeration time was adjusted by using timers for each blower (Figs. 1 and 2).

\section{Investigated variables:}

The present study was conducted to investigate the following compost factors:

- Two modes of forced aeration namely: continuous and intermittent aeration;

- One level of continuous aeration: $(60 \mathrm{~min} / \mathrm{h})$

- Three levels of intermittent aeration: (45, 30 and $15 \mathrm{~min} / \mathrm{h})$ and;

- Three aeration rates of $0.13,0.16$ and $0.19 \mathrm{~m}^{3} / \mathrm{h}$.

The influence of the investigated factors on the compost temperature, moisture content, $\mathrm{pH}$ with the composting time was studied. As well as, some physicochemical properties of the final compost product were measured.

\section{Determination of the quantity of poultry litter added to cotton stalks (mixture ratio):}

The quantity of poultry litter added to each $\mathrm{kg}$ of cotton stalks to adjust Carbon:Nitrogen (C:N) ratio 32:1 was determined using following formula (Esther and Julie, 2001):

$C: N$ ratio $=\frac{C \text { in cotton stalks, } k g+(X) C \text { in poultry litter, } k g}{N \text { in cotton stalks, } k g+(X) N \text { in poultry litter, } k g} \ldots \ldots \ldots . . .1$ 
Where:

$X \quad$ quantity of poultry litter which must be added to one $\mathrm{kg}$ of cotton stalks, kg.

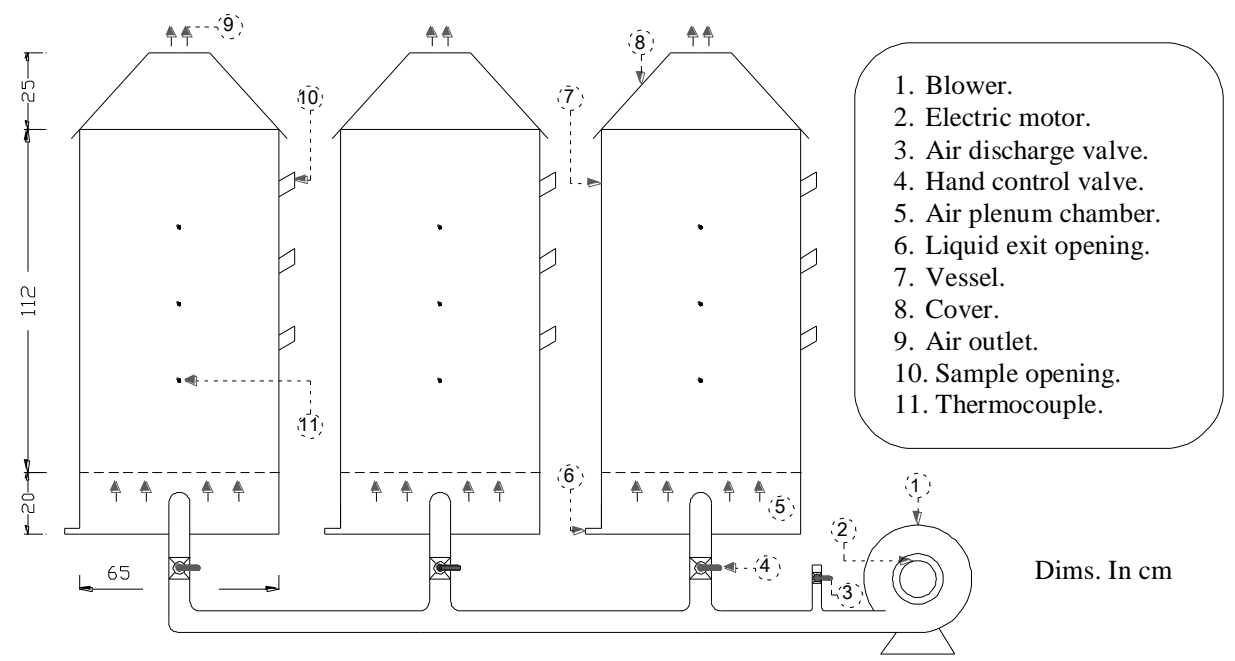

Fig. 1: Schematic diagram of composting system.
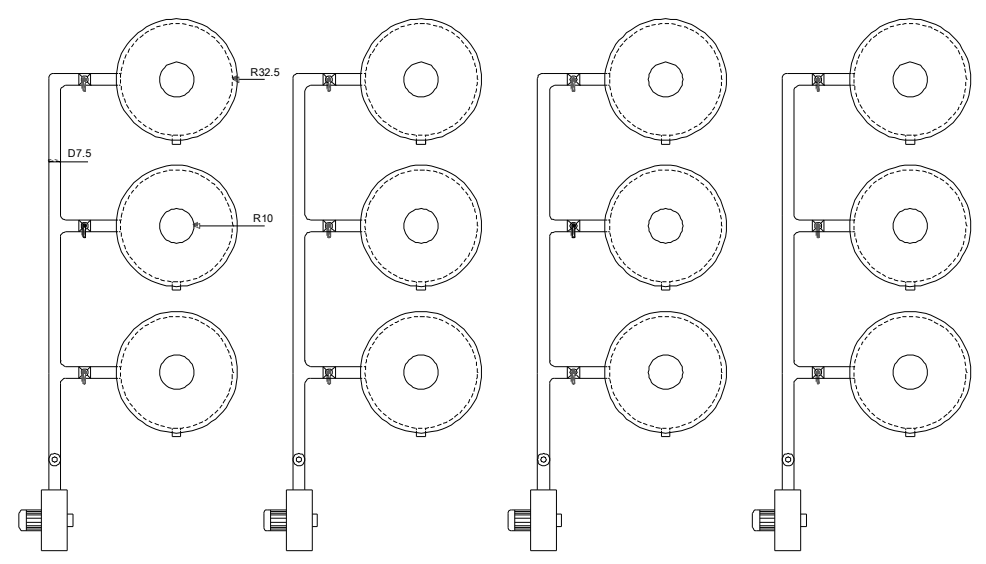

Fig. 2: Plan view of compost vessels.

Dims. In cm 


\section{Compost temperature:}

To measure the compost temperature, three thermocouples were fixed in the compost core for each vessel at 30,55 and $80 \mathrm{~cm}$ high from the bottom surface of the vessel. The J-type thermocouples were connected with a digital thermometer (Model: HH-26J-USA) to record the compost temperature at the three different levels and thereafter the averaged values can be obtained. Two thermocouples were connected with the digital thermometer to record the ambient temperature and the averaged values were calculated. Compost temperature was measured daily during the composting process in the Noon time.

\section{Compost moisture content:}

The highest microbial activity during composting process, was maintained in the range of $60-70 \%$ moisture while, $50 \%$ moisture content seems to be the minimum requirement for rapid increase in microbial activity according to (Laing et al., 2003). Triplicate compost samples were taken every week for determining the moisture content on a wet basis using the oven method (by drying at $105^{\circ} \mathrm{C}$ to constant mass). Three samples were taken from each vessel at 42,67 and $92 \mathrm{~cm}$ high from the bottom surface of the vessel and the averaged values were calculated.

\section{Analytical procedures:}

The $\mathrm{pH}$ was determined with a probe on $5 \mathrm{~g}$ of sample soaked in $50 \mathrm{ml}$ of distilled water (1:10 weight/volume) for $24 \mathrm{~h}$. Triplicate compost samples were taken every week for determining the $\mathrm{pH}$. Electrical conductivity, Total nitrogen, Total organic carbon and bulk density were measured on the initial and final samples. Electrical conductivity (EC, dS/m) was determined according to the method described by Chen et al., 1988. $5 \mathrm{~g}$ sample was mixed with $50 \mathrm{ml}$ distilled water $(1: 5 \mathrm{w} / \mathrm{v})$, shaken for $2 \mathrm{~h}$ and filtered. The EC was measured in the filtrate using conductivity meter (Jenway $\mathrm{PcM}^{3}$, Germany). Total nitrogen $(\mathrm{N}, \mathrm{g} / \mathrm{kg}$ ) was determined by the semi-micro Kjeldahl digestion followed by steam distillation and titration methods as described by Page et al., 1982. Total organic carbon (C, g/kg) was determined by Walkley-Black method as outlined by Page 
et al., 1982. C/N ratio was calculated as the ratio between total organic carbon and total nitrogen. Total organic matter $(\mathrm{g} / \mathrm{kg})$ was calculated from the total organic carbon as described by Page et al., 1982. The bulk density was determined by filling container of known volume and weight with the materials and the filled container was weighed. The bulk density $\left(\mathrm{kg} / \mathrm{m}^{3}\right)$ equals the filled container weight minus the empty container weight divided by the container volume. The compost samples were analyzed at Soils and Water Research Laboratories, Sakha station, Kafrelsheikh governorate, Egypt.

\section{RESULTS AND DISCUSSION}

\section{Temperature profile:}

Figs. 3, 4, 5 and 6 show the average temperature profile (compost, ambient and difference temperature) at different modes of forced aeration and various aeration rates during the composting process. A rapid increase in temperature were observed in all vessels at the beginning just after putting the compost mixture in the vessels, depending on the aeration conditions, indicating a remarkable microbial activity. The temperature within a composting material determines the rate at which many of the biological processes take place and plays a selective role on the evolution and the succession of the microbiological communities. For continuous aeration and aeration rate of $0.16 \mathrm{~m}^{3} / \mathrm{h}$ Fig. 3 and Table 2 show that, during the mesophilic stage (warming up), the compost temperature increased and reached $41.25^{\circ} \mathrm{C}$ within 15 days from the beginning of composting time. While, the thermophilic stage lasted 16 days and the maximum compost temperature (peak temperature) inside the vessel $\left(59.35^{\circ} \mathrm{C}\right)$ was reached within 31 days from the starting point of composting. During the cooling down stage, the compost temperature decreased and reached $26.21^{\circ} \mathrm{C}$ within 84 days from the beginning of composting time. At the end of composting time, the difference between both of ambient and compost temperature was of $5.98^{\circ} \mathrm{C}$. For intermittent aeration of $45 \mathrm{~min} / \mathrm{h}$ and different aeration rates of $0.13,0.16$ and $0.19 \mathrm{~m}^{3} / \mathrm{h}$ Fig. 4 and Table 2 showed that, the compost temperature at thermophilic stage increased and reached $57.86,59.83$ and $54.49^{\circ} \mathrm{C}$ after 35, 30 and 33 days respectively. During the cooling down and maturing 
stage, the compost temperature decreased and reached 28.97, 27.49 and $25.11^{\circ} \mathrm{C}$ after 85,82 and 87 days respectively. The difference between both of ambient and compost temperature was of $6.4,3.8$ and $2.4^{\circ} \mathrm{C}$ at the end of composting time respectively.
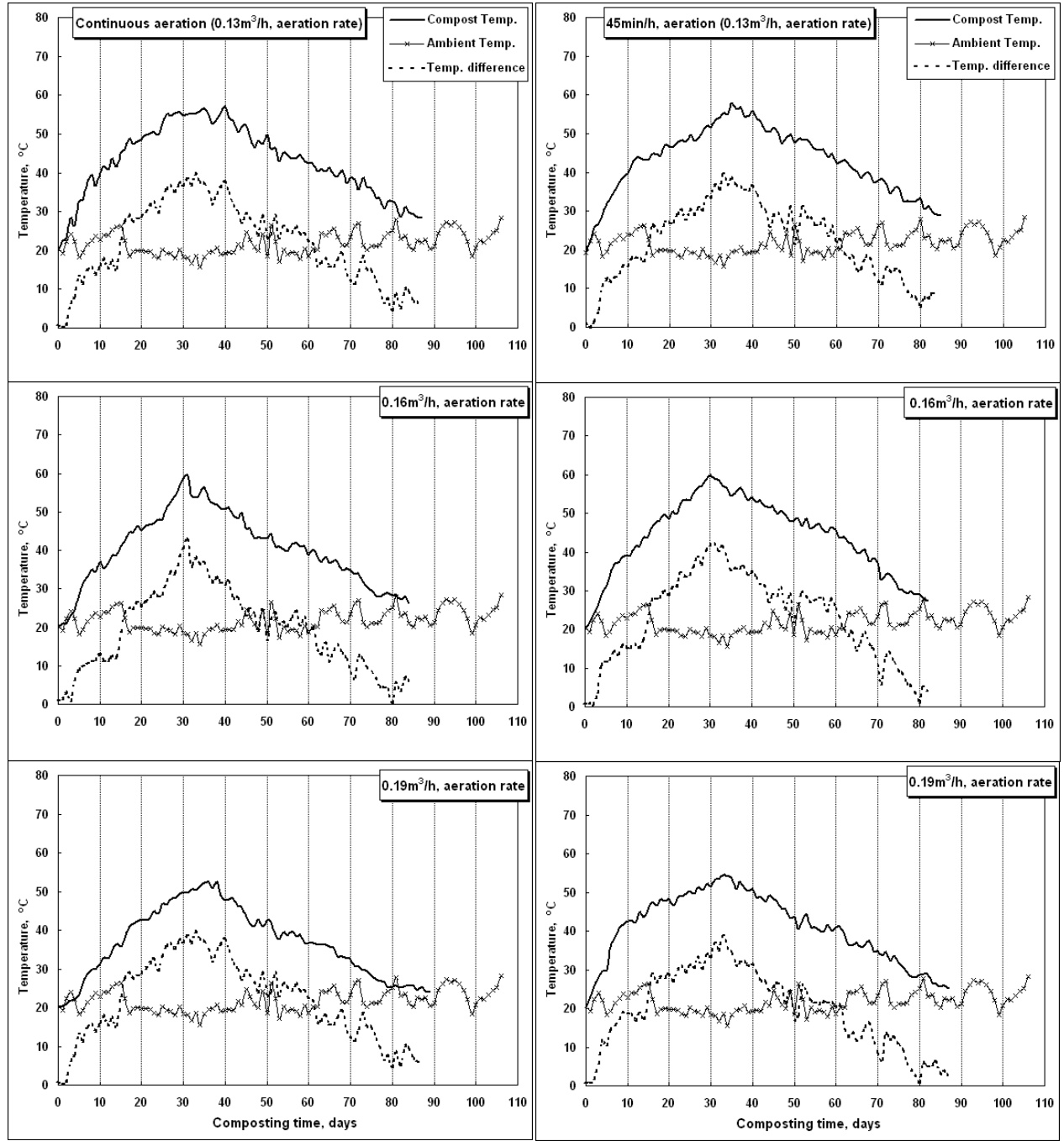

Fig. 3: Variation of temperature during composting time at continuous aeration and different aeration rates.
Fig. 4: Variation of temperature during composting time at intermittent aeration of $45 \mathrm{~min} / \mathrm{h}$ and different aeration rates. 

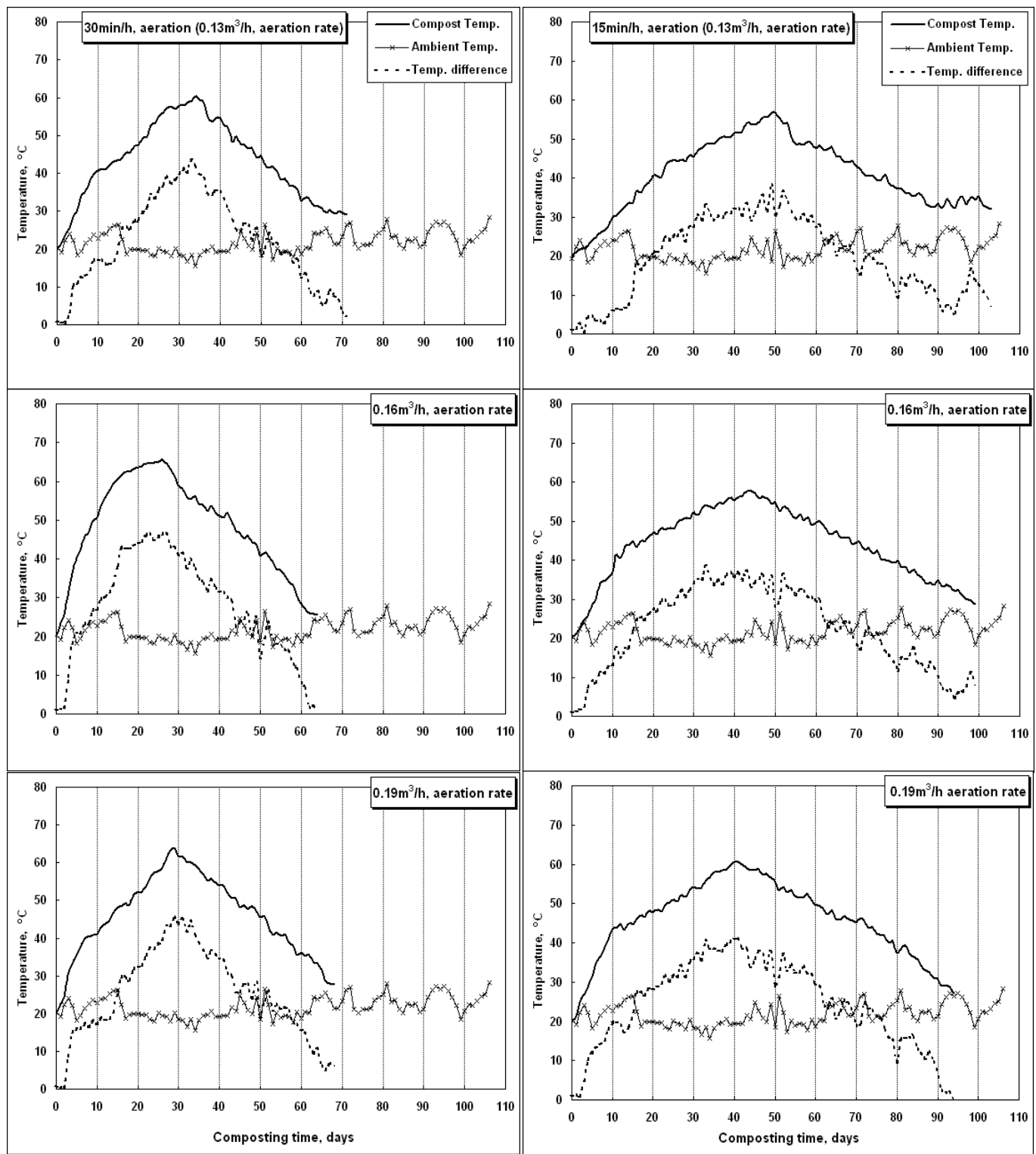

Fig. 5: Variation of temperature during composting time at intermittent aeration of $30 \mathrm{~min} / \mathrm{h}$ and different aeration rates.

Fig. 6: Variation of temperature during composting time at intermittent aeration of $15 \mathrm{~min} / \mathrm{h}$ and different aeration rates. 
Table 2: Average temperature of compost and ambient versus time at different aeration period and various aeration rates.

\begin{tabular}{|c|c|c|c|c|c|c|c|c|c|c|}
\hline \multirow{2}{*}{$\begin{array}{c}\text { Forced } \\
\text { aeration } \\
\text { modes }\end{array}$} & \multirow{2}{*}{$\begin{array}{l}\text { Aeration } \\
\text { rate, } \\
\mathrm{m}^{3} / \mathrm{h}\end{array}$} & \multicolumn{3}{|c|}{$\begin{array}{l}\text { Mesophilic stage } \\
\text { (warming up) }\end{array}$} & \multicolumn{3}{|c|}{$\begin{array}{l}\text { Thermophilic stage } \\
\text { (peak temperature) }\end{array}$} & \multicolumn{3}{|c|}{$\begin{array}{l}\text { Cooling down and } \\
\text { maturing stage }\end{array}$} \\
\hline & & $\left|\begin{array}{l}\text { Compost } \\
\text { temp., }{ }^{\circ} \mathrm{C}\end{array}\right| \mathrm{t}$ & time, & $\begin{array}{l}\text { Ambient } \\
\text { temp., }{ }^{\circ} \mathrm{C}\end{array}$ & $\begin{array}{l}\text { Compost } \\
\text { temp., }{ }^{\circ} \mathrm{C}\end{array}$ & time, & $\begin{array}{l}\text { Ambient } \\
\text { temp., }{ }^{\circ} \mathrm{C}\end{array}$ & $\left|\begin{array}{l}\text { Compost } \\
\text { temp. },{ }^{\circ} \mathrm{C}\end{array}\right|$ & time, & $\begin{array}{l}\text { Ambient } \\
\text { temp., }{ }^{\circ} \mathrm{C}\end{array}$ \\
\hline \multirow{3}{*}{ Continuous } & 0.13 & 41.78 & 11 & 23.99 & 56.47 & 35 & 19.42 & 28.35 & 87 & 22.67 \\
\hline & 0.16 & 41.25 & 15 & 22.46 & 59.35 & 31 & 16.61 & 26.21 & 84 & 20.23 \\
\hline & 0.19 & 40.92 & 17 & 19.81 & 52.54 & 38 & 19.11 & 24.11 & 89 & 21.22 \\
\hline \multirow{3}{*}{$45 \mathrm{~min} / \mathrm{h}$} & 0.13 & 41.85 & 11 & 23.99 & 57.86 & 35 & 19.42 & 28.97 & 85 & 22.57 \\
\hline & 0.16 & 41.36 & 12 & 25.41 & 59.83 & 30 & 18.15 & 27.49 & 82 & 23.62 \\
\hline & 0.19 & 40.97 & 8 & 23.70 & 54.49 & 33 & 15.62 & 25.11 & 87 & 22.67 \\
\hline \multirow{3}{*}{$30 \mathrm{~min} / \mathrm{h}$} & 0.13 & 40.78 & 10 & 23.89 & 60.34 & 34 & 18.31 & 29.12 & 71 & 26.97 \\
\hline & 0.16 & 40.35 & 5 & 19.41 & 65.45 & 26 & 19.16 & 25.49 & 64 & 24.57 \\
\hline & 0.19 & 40.87 & 9 & 22.80 & 63.72 & 29 & 18.36 & 27.61 & 68 & 21.41 \\
\hline \multirow{3}{*}{$15 \mathrm{~min} / \mathrm{h}$} & 0.13 & 40.69 & 20 & 19.71 & 56.77 & 50 & 26.46 & 31.92 & 103 & 24.55 \\
\hline & 0.16 & 40.37 & 12 & 25.41 & 57.76 & 44 & 24.71 & 28.66 & 99 & 20.61 \\
\hline & 0.19 & 40.66 & 9 & 22.80 & 60.52 & 41 & 19.36 & 27.24 & 94 & 26.13 \\
\hline
\end{tabular}

For intermittent aeration of $30 \mathrm{~min} / \mathrm{h}$ and different aeration rates of 0.13 , 0.16 and $0.19 \mathrm{~m}^{3} / \mathrm{h} \mathrm{Fig.} 5$ and Table 2 showed that, during the mesophilic stage (warming up), the compost temperature increased and reached $40.78,40.35$ and $40.87^{\circ} \mathrm{C}$ within 10,5 and 9 days from the starting point of composting respectively. Also during the thermophilic stage (peak temperature), the compost temperature increased and reached 60.34, 65.45 and $63.72^{\circ} \mathrm{C}$ after 34,26 and 29 days of composting respectively. During the cooling down and maturing stage, the compost temperature decreased and reached 29.12, 25.49 and $27.61^{\circ} \mathrm{C}$ after 71,64 and 68 days of composting respectively. The difference between both of ambient and compost temperature was of $2.15,0.92$ and $6.2^{\circ} \mathrm{C}$ at the end of composting time respectively. Both the thermophilic and stabilization phases may be last anywhere from 10 to 100 days, depending on the materials being composted and the methods or technologies employed (Keener et al., 2000). For intermittent aeration of $15 \mathrm{~min} / \mathrm{h}$ and different aeration rates of $0.13,0.16$ and $0.19 \mathrm{~m}^{3} / \mathrm{h}$ Fig. 6 and Table 2 show that, during the mesophilic stage the compost temperature increased and 
reached $40.69,40.37$ and $40.66^{\circ} \mathrm{C}$ within 20,12 and 9 days from the beginning of composting time respectively. In case of the thermophilic stage, the compost temperature increased and reached 56.77, 57.76 and $60.52^{\circ} \mathrm{C}$ after 50,44 and 41 days of composting respectively. Concerning the cooling down and maturing stage, the compost temperature decreased and reached 31.92, 28.66 and $27.24^{\circ} \mathrm{C}$ after 103, 99 and 94 days of composting respectively. The difference between both of ambient and compost temperature was of $7.37,8.05$ and $1.11^{\circ} \mathrm{C}$ at the end of composting time respectively. Comparing the values of forced aeration for continuous and intermittent at different aeration rates, the results showed that, the intermittent aeration of $30 \mathrm{~min} / \mathrm{h}$ and the aeration rate of $0.16 \mathrm{~m}^{3} / \mathrm{h}$ have achieved the maximum temperature of compost of about $65.45^{\circ} \mathrm{C}$ after 26 days from the starting point of composting for thermophilic stage. This means that the composting process has the highest rate in lowest time at the same above mentioned conditions. The temperature has been widely recognized as one of the most important parameters in the composting process. The rise and fall in temperature have been found to strongly correlate with the microbial activity. The temperature exceeding $55^{\circ} \mathrm{C}$ is necessary to destroy the pathogens in composting mixture for at least three consecutive days this results agree with (Zhang and $\mathrm{He}$, 2006).

\section{Moisture level in compost vessels:}

For all vessels, initial moisture content of about $61.53 \%$ decreased gradually during composting process (Fig. 7). The results showed that the amount of moisture lost during composting process depends on different aeration periods and various aeration rates. A positive relationship was found between moisture reduction and increase of aeration rate. The main mechanism of water removal in this composting process was the evaporation of water as a consequence of microbial heat generation. Water evaporation caused a continuous heat removal in forced aeration and dried the compost material progressively. The continuous decrease in moisture content during composting is an indication of organic matter decomposition. For continuous aeration and different aeration rates of $0.13,0.16$ and $0.19 \mathrm{~m}^{3} / \mathrm{h}$ Fig. 7 shows that, the compost moisture content decreased and reached 28.15, 27.04 and $25.37 \%$ in week 13 of 
composting respectively. While, intermittent aeration of $30 \mathrm{~min} / \mathrm{h}$ and the same previous aeration rates, the compost moisture content decreased and reached $31.87,30.12$ and $28.36 \%$ in week 11 of composting respectively. In the same time the intermittent aeration of $30 \mathrm{~min} / \mathrm{h}$ and different aeration rates, moisture loss was faster than the other treatments this may be due to the higher temperature degree of compost as shown in Fig. 5. These findings are the same trend with those obtained by Kulcu and Yaldiz 2004. For intermittent aeration of $45 \mathrm{~min} / \mathrm{h}$ and different aeration rates of $0.13,0.16$ and $0.19 \mathrm{~m}^{3} / \mathrm{h}$ Fig. 7 shows that, the compost moisture content decreased and reached 31.83, 29.67 and $28.44 \%$ in week 12 of composting respectively. However, the intermittent aeration of $15 \mathrm{~min} / \mathrm{h}$, the compost moisture content decreases by $31.11,29.62$ and $27.35 \%$ in week 15 of composting respectively at the same above mentioned aeration rates.

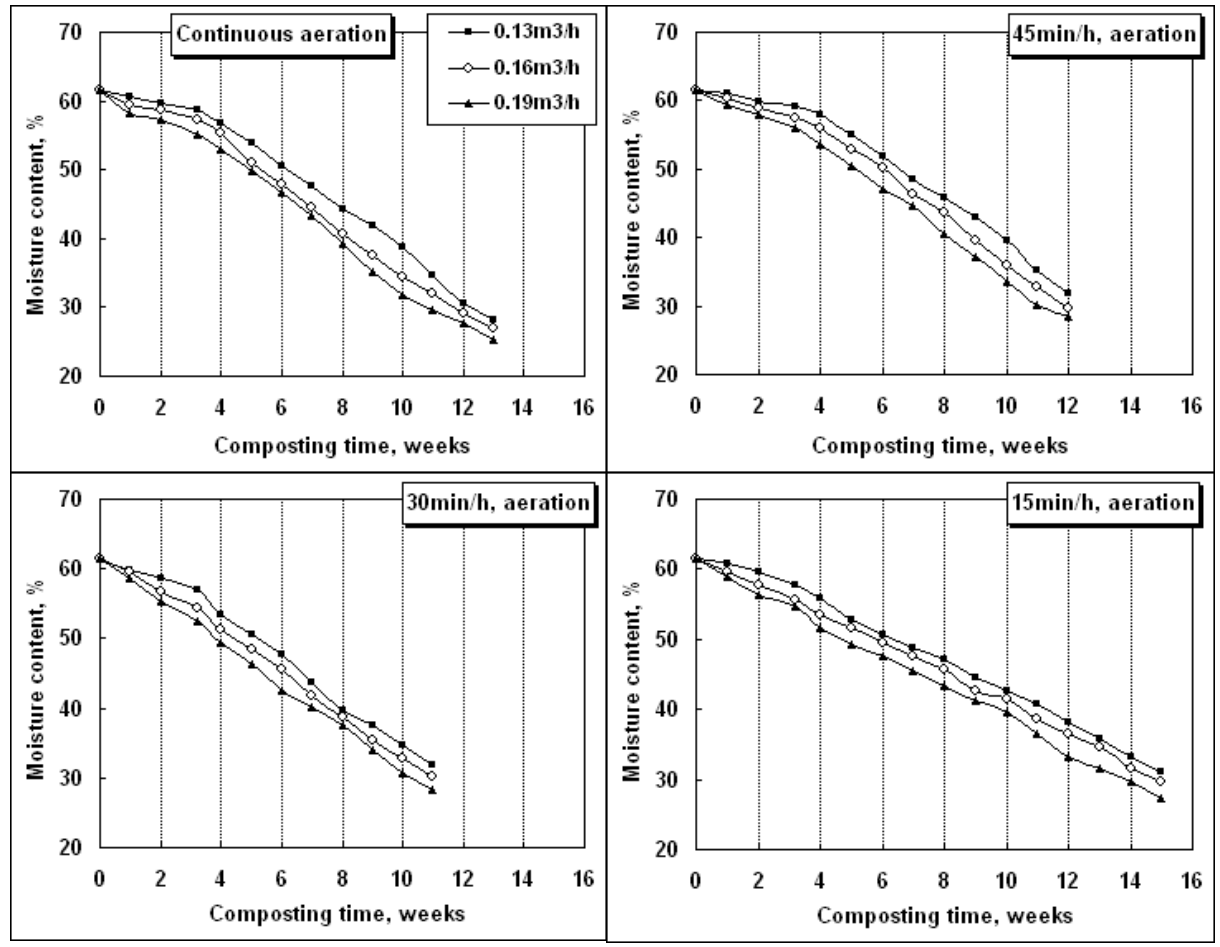

Fig. 7: Variation of moisture content during composting time at different modes of forced aeration and various aeration rates. 


\section{Evolution of pH:}

Fig. 8 shows $\mathrm{pH}$ changes during the composting of poultry litter and cotton stalks at different modes of forced aeration and various aeration rates. In general, the $\mathrm{pH}$ was maintained at 6.56 to 8.52 during the composting processes for all treatments. The ideal $\mathrm{pH}$ range for microbial activity is between 6.5 and 8.0. Composting continues at extremes, such as 5 and 9, but the process slow. For continuous aeration, the $\mathrm{pH}$ value for different aeration rates of $0.13,0.16$ and $0.19 \mathrm{~m}^{3} / \mathrm{h}$ increased from 7.15 to $7.62,7.78$, and 7.91 in week 13 respectively. At the outset, the $\mathrm{pH}$ gradually decreased to 6.75 for aeration rate of $0.13 \mathrm{~m}^{3} / \mathrm{h}$ in week 5 , and then increased.

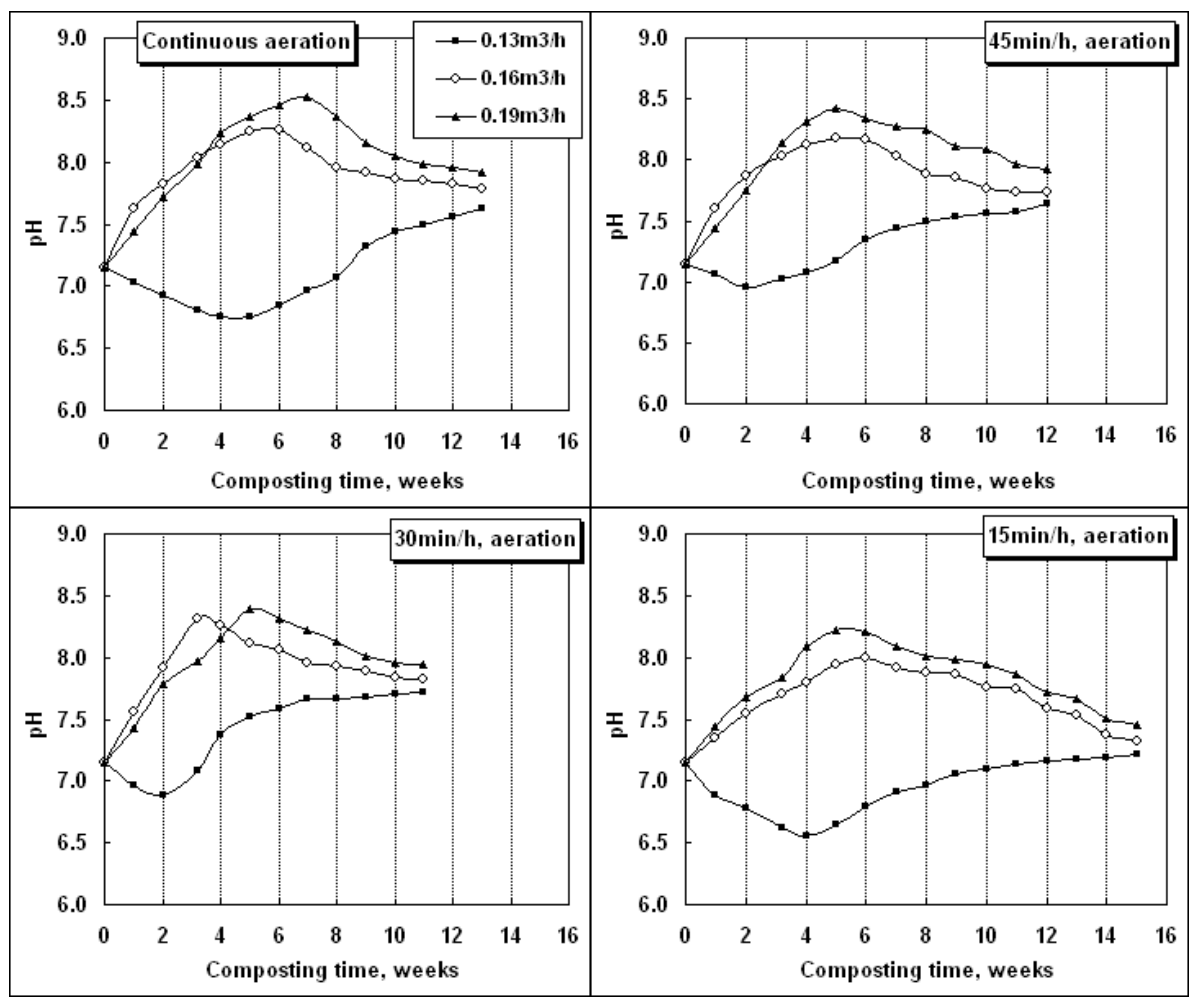

Fig. 8: Variation of $\mathrm{pH}$ during composting time at different modes of forced aeration and various aeration rates. 
This could be attributed to the production of organic acids which component from anaerobic conditions which accrued by the low aeration rate. In contrast, the $\mathrm{pH}$ gradually increased to 8.26 and 8.52 for aeration rate of 0.16 and $0.19 \mathrm{~m}^{3} / \mathrm{h}$ in weeks 6 and 7 respectively, and then decreased. This is suggested as being related to the low production of organic acids and the large ammonia emissions under aerobic conditions. For intermittent aeration of $45 \mathrm{~min} / \mathrm{h}$, the $\mathrm{pH}$ value for different aeration rates of $0.13,0.16$ and $0.19 \mathrm{~m}^{3} / \mathrm{h}$ increased from 7.15 to $7.64,7.73$, and 7.93 in week 12 respectively. The acidic $\mathrm{pH}$ of the compost indicates a lack of maturity due to short composting time or the occurrence of anaerobic process in the vessel. The $\mathrm{pH}$ should be prevented from rising above 8.5 minimize the gaseous loss of nitrogen in the form of ammonia. For intermittent aeration of $30 \mathrm{~min} / \mathrm{h}$, the $\mathrm{pH}$ value for different aeration rates of $0.13,0.16$ and $0.19 \mathrm{~m}^{3} / \mathrm{h}$ increased from 7.15 to $7.72,7.82$, and 7.94 in week 11 respectively. For intermittent aeration of $15 \mathrm{~min} / \mathrm{h}$, the $\mathrm{pH}$ value for different aeration rates of $0.13,0.16$ and $0.19 \mathrm{~m}^{3} / \mathrm{h}$ increased from 7.15 to $7.21,7.32$, and 7.46 in week 15 respectively.

\section{Physicochemical properties:}

Some physicochemical properties of initial composting mixture and the final product are presented in Table 3. Electrical conductivity reflects the degree of salinity in the compost product, which indicates its possible phytotoxic/phyto-inhibitory effects (e.g. low germination rate, withering) on the growth of plants. In all vessels, electrical conductivity values increased for the final compost materials. These high values could be due to the effect of the concentration of salts as a consequence of the degradation of organic matter. The highest value of electrical conductivity of the final compost materials was found to be $4.62 \mathrm{dS} / \mathrm{m}$ for intermittent aeration of $15 \mathrm{~min} / \mathrm{h}$ and aeration rate of $0.13 \mathrm{~m}^{3} / \mathrm{h}$. The bulk density of the final compost materials were declined in all cases. The results indicated that the bulk density decreased by a percent ranged from 34.8 to $13.9 \%$ depending on the aeration conditions. The lowest bulk density of the final compost materials was found to be $236.48 \mathrm{~kg} / \mathrm{m}^{3}$ for intermittent aeration of $30 \mathrm{~min} / \mathrm{h}$ and aeration rate of $0.16 \mathrm{~m}^{3} / \mathrm{h}$. 
Table 3: Some physicochemical properties of initial mixture and the final product for all treatments.

\begin{tabular}{|c|c|c|c|c|c|c|c|c|c|c|c|c|c|}
\hline \multirow{4}{*}{ Parameter } & \multirow{4}{*}{$\begin{array}{c}\text { Initial } \\
\text { composting } \\
\text { mixture }\end{array}$} & \multicolumn{12}{|c|}{ Final composting product } \\
\hline & & \multicolumn{12}{|c|}{ Aeration modes and its rates $\left(\mathrm{m}^{3} / \mathrm{h}\right)$} \\
\hline & & \multicolumn{3}{|c|}{ Continuous } & \multicolumn{3}{|c|}{$45 \mathrm{~min} / \mathrm{h}$} & \multicolumn{3}{|c|}{$30 \mathrm{~min} / \mathrm{h}$} & \multicolumn{3}{|c|}{$15 \mathrm{~min} / \mathrm{h}$} \\
\hline & & 0.13 & 0.16 & 0.19 & 0.13 & 0.16 & 0.19 & 0.13 & 0.16 & 0.19 & 0.13 & 0.16 & 0.19 \\
\hline Electrical conductivity, dS/m & 3.87 & 4.41 & 4.38 & 4.31 & 4.27 & 4.24 & 4.22 & 4.15 & 4.12 & 4.11 & 4.62 & 4.57 & 4.53 \\
\hline Bulk density, $\mathrm{kg} / \mathrm{m}^{3}$ & 362.47 & 281.98 & 273.43 & 268.23 & 278.25 & 265.48 & 263.83 & 261.85 & 236.48 & 251.18 & 312.21 & 303.09 & 300.31 \\
\hline Total organic carbon, $\mathrm{g} / \mathrm{kg}$ & 348.75 & 288.64 & 285.62 & 282.76 & 284.65 & 280.64 & 277.51 & 279.82 & 275.87 & 275.64 & 304.52 & 301.67 & 299.67 \\
\hline Total nitrogen, $\mathrm{g} / \mathrm{kg}$ & 10.89 & 12.45 & 12.87 & 12.76 & 13.68 & 13.96 & 13.84 & 14.78 & 15.76 & 15.59 & 10.91 & 11.34 & 11.26 \\
\hline $\mathrm{C} / \mathrm{N}$ ratio & $32: 1$ & 23.18 & 22.19 & 22.16 & 20.81 & 20.10 & 20.05 & 18.93 & 17.50 & 17.68 & 27.91 & 26.60 & 26.61 \\
\hline Total organic matter, $\mathrm{g} / \mathrm{kg}$ & 453.23 & 380.23 & 375.59 & 369.76 & 402.23 & 397.59 & 387.76 & 413.23 & 412.59 & 402.76 & 349.23 & 343.59 & 339.76 \\
\hline Loss, \% & & 16.11 & 17.13 & 18.42 & 11.25 & 12.28 & 14.45 & 8.83 & 8.97 & 11.14 & 22.95 & 24.19 & 25.04 \\
\hline
\end{tabular}


In the opposite side, the highest value of bulk density of the final compost materials was found to be $312.21 \mathrm{~kg} / \mathrm{m}^{3}$ for intermittent aeration of $15 \mathrm{~min} / \mathrm{h}$ and aeration rate of $0.13 \mathrm{~m}^{3} / \mathrm{h}$. Composting leads to a volume reduction of one-quarter to more than one-half of the initial volume, depending upon the raw materials. Typical agricultural materials exhibit a large shrinkage in volume. Part of this volume reduction represents the loss of $\mathrm{CO}_{2}$ and water to the atmosphere. Part of it occurs as loose, bulky raw materials are changed into crumbly, fine-textured compost. The composting materials also experience a large weight reduction, on the order of 40-80\%, mostly because of water loss. The percent reduction of the total organic carbon ranged from 12.68 to $20.96 \%$ depending on the aeration conditions. The highest reduction percents were found with the aeration rate $0.19 \mathrm{~m}^{3} / \mathrm{h}$ and intermittent aeration of $30 \mathrm{~min} / \mathrm{h}$. Composting time is also affected by the rate of decomposition of carbon compounds from different organic materials. Increasing in total nitrogen was observed with all treatments. The highest value of total nitrogen was noticed in the produced from intermittent aeration $30 \mathrm{~min} / \mathrm{h}$ and $0.16 \mathrm{~m}^{3} / \mathrm{h}$ aeration rate. This results agree with (Kulcu and Yaldiz, 2004). The total organic matter loss was in the range from 8.83 to $25.04 \%$ depending on the aeration conditions. The results showed that with increasing of the aeration rate and its period the total organic matter loss increased. The maximum total organic matter loss was found with aeration rate $0.19 \mathrm{~m}^{3} / \mathrm{h}$ and continuous aeration.

\section{CONCLUSIONS}

The intermittent aeration of $30 \mathrm{~min} / \mathrm{h}$ and the aeration rate of $0.16 \mathrm{~m}^{3} / \mathrm{h}$ have accomplished the highest temperature in lowest time during composting process, this leads to high degradation rate for initial compost mixture, as a result, the same operating conditions achieved the best physicochemical characteristics of final compost product in comparison with the other factors under study. The lowest difference between both of ambient and final compost product temperature was of $0.92^{\circ} \mathrm{C}$ at intermittent aeration of $30 \mathrm{~min} / \mathrm{h}$ and the aeration rate of $0.16 \mathrm{~m}^{3} / \mathrm{h}$. 


\section{REFERENCES}

Ahn, H. K.; T. L. Richard and H. L. Choi (2007). Mass and thermal balance during composting of poultry manure-wood shavings mixture at different aeration rates. Process Biochem., 42: 215-223.

Chen, Y.; Y. Inbar and Y. Hadar (1988). Composted agricultural wastes as potting media for ornamental plants. Soil Science, 145(4): 298303.

Esther, B. and B. Julie (2001). Design and implementation a composting system for a community food bank and darden. Agricultural and bio-system engineering, A technical report, McGill Unversity, Canada.

Hassen, A.; K. Belguith; N. Jedidi and A. Cherif (2001). Microbial characterization during composting of municipal solid waste. Bioresour. Technol. 80: 217-225.

Hong, J. H.; J. Matsuda and Y. Ikeuchi (1983). High rapid composting of dairy cattle manure with crop and forest residues. Trans. ASAE., 26: 533-545.

Keener, H. M.; K. Ekinci; D. L. Elwell and F. C. Michel (2000). Mathematics of composting facility design and process control. In Warman, P. R. and B. R. Taylor (Eds.). Proceedings of the International Composting Symposium (ICS), September 1923/1999, Halifax, NS., 164-197.

Kim, J.; I. Song; J. Jong; S. Lee; P. Kim; E. Jeong; J. Park and Y. Choung (2009). Influence of aeration rate on nitrogen during blackwater composting. Desalination 248: 298-307.

Kulcu and Yaldiz (2004). Determination of aeration rate and kinetic composting some agricultural waste. Bioresource Technology. 93(1): 49-57.

Kuter, G. A.; H. A. J. Hoitink and L. A. Rossman (1985). Effects of aeration and temperature on composting of municipal sludge in a full-scale vessel system. J. Water Pollut. Contr. Fed., 57: 309-315.

Lau, A. K.; K. V. Lo; P. H. Liao and J. C. Yu (1992). Aeration experiments for swine waste composting. Bioresour. Technol., 41: $145-152$. 
Li, X.; R. Zhang and Y. Pang (2008). Characteristics of dairy manure composting with rice straw. Bioresour. Technol., 99(2): 359-367.

Liang, C. K.; C. Das and R. W. McClendon (2003). The influence of temperature and moisture content regimes on the aerobic microbial activity of a biosolids composting blend. Bioresource technology., 86(1): 131-137.

Lu, S. G.; T. Imai; H. F. Li; M. Ukita; M. Sekine and T. Higuchi (2001). Effect of enforced aeration on in-vessel food waste composting. Environ. Technol., 22: 1177-1182.

Page, A. L.; R. H. Miller and D. R. Keeney (1982). Method of soil analysis, Chemical and microbiological properties. $2^{\text {nd }}$ Edition, Agronomy, ASA, SSSA Published, Madison, Wisconsin, USA., 9: 1159.

Pereia-Neto, J. T.; E. I. Stentiford and D. D. Mara (1987). Low cost controlled of composting of refuse and sewage sludge. Water Sci. Technol., 19: 839-845.

Polprasert, C. (1996). Organic waste recycling: Technology and Management, second ed. Wiley, Chichester, 69-113.

Rasapoor, M.; T. Nasrabadi; M. Kamali and H. Hoveidi (2009). The effects of aeration rates on generated compost quality, using aerated static pile method. Waste Manage., 29: 570-573.

Smet, E.; H. Van Langenhove and I. De Bo (1999). The emission of volatile compounds during the aerobic and the combined anaerobic/aerobic composting of biowaste. Atmos. Environ., 33: 1295-1303.

Solano, M. L.; F. Iriarte; P. Ciria and M. J. Negro (2001). Performance characteristics of three aeration systems in the composting of sheep manure and straw. J. Agric. Eng. Res., 79(3): 317-329.

Tiquia, S. M. and N. F. Y. Tam (2002). Characterization and composting of poultry litter in forced-aeration piles. Process Biochemistry., 37(8): 869-880.

Trois, C. and A. Polster (2001). Effective pine bark composting with the Dome Aeration Technology. Waste Manage., 27: 96-105. 
Zhang, Y. and Y. He (2006). Co-composting solid swine manure with pine sawdust as organic substrate. Bioresour. Technol., 97: 20242031.

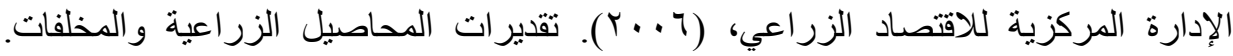

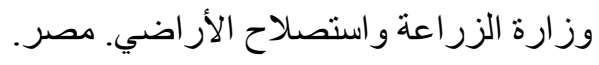

الملخص العربي

\section{تأثير التهوية المستمرة والمثقطعة على التمبئ إنتاج}

كمبوست فرشة الاجاج وحطب القطن

د/محمد عبا الحميا بسيونى

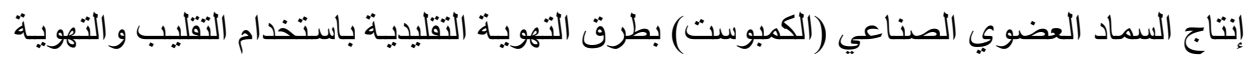

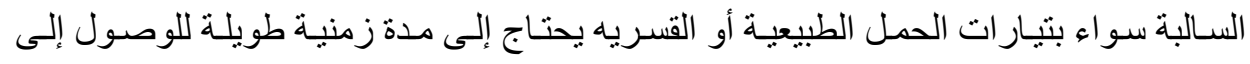

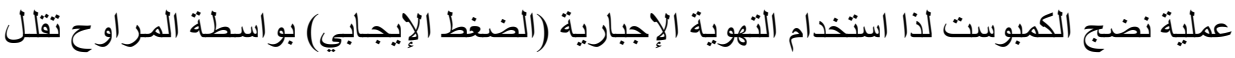

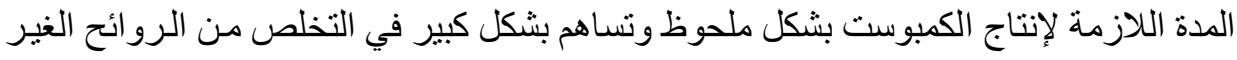

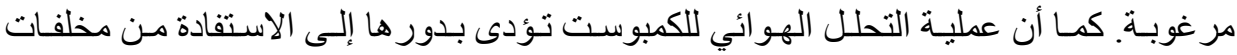

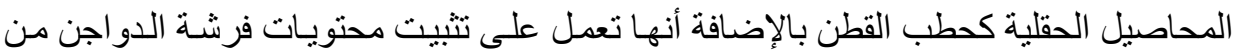

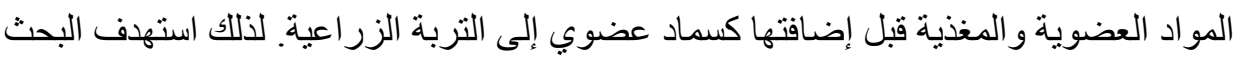

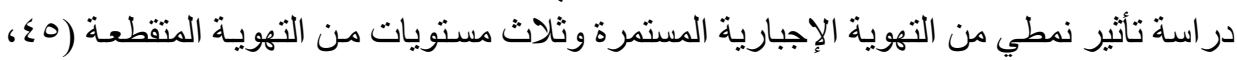

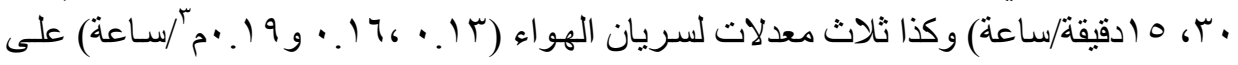

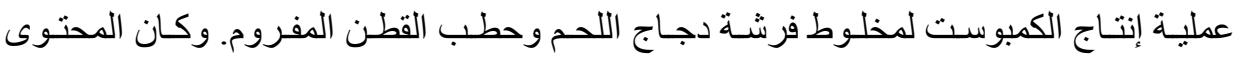

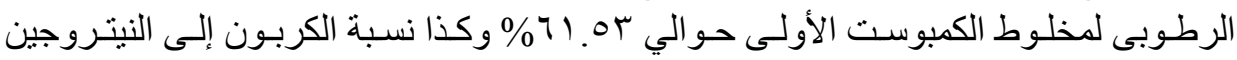

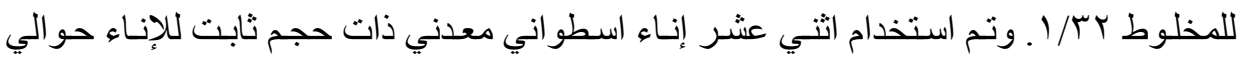

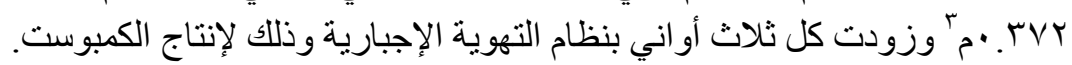

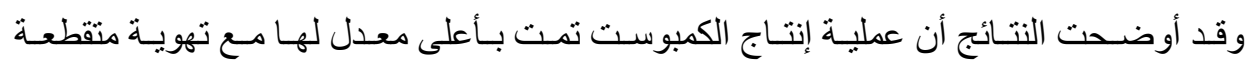

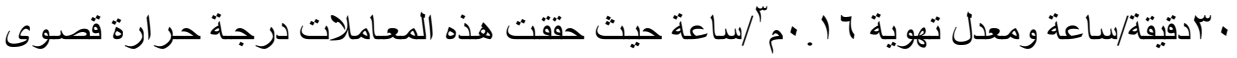

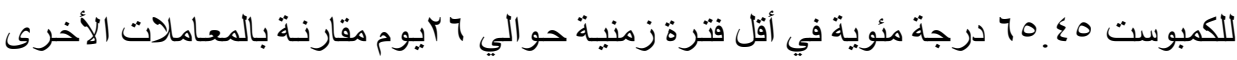

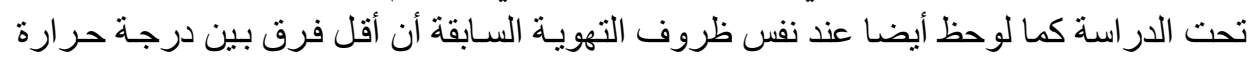

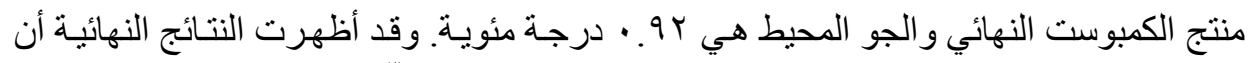

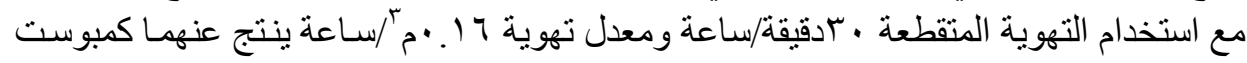
عالي الجودة في خو اصه الفيزوكيميائيه بالمقارنة بالعو امل الأخرى تحت الدئة الدراسة.

* باحث أول بمعه بحوث الهندة الزراعية ـ مركز البحوث الزراعية ـ الجيزة ـ مصر. 